\title{
The effect of protein- and non-protein-nitrogen supplements to maize silage on total amino acid supply in young cattle
}

\author{
By B. R. COTTRILL*, D. E. BEEVER, A. R. AUSTIN AND D. F. OSBOURN \\ The Grassland Research Institute, Hurley, Maidenhead, Berkshire SL6 5LR
}

(Received 12 August 1981-Accepted 4 June 1982)

\begin{abstract}
1. A total of six diets based on maize silage were formulated to examine the effect of protein- and non-protein-nitrogen, and energy supplementation on the flow of amino acids to the small intestine and the synthesis of microbial amino acids in the rumen of growing cattle. All diets contained $24 \mathrm{~g}$ total nitrogen (N)/ $\mathrm{kg}$ dry matter (DM), of which $550 \mathrm{~g} \mathrm{~N} / \mathrm{kg}$ total $\mathrm{N}$ was supplied by either urea or fish meal. Four diets contained low levels of barley (estimated total dietary metabolizable energy content of $10.4 \mathrm{MJ} / \mathrm{kg} \mathrm{DM}$ ) and urea- $\mathrm{N}$ and fish meal-N were supplied in the ratios $3: 1,1 \cdot 4: 1,0.6: 1$ and $0.3: 1$. The other two diets contained between 300 and $400 \mathrm{~g}$ barley/ $\mathrm{kg}$ total diet (11.3 MJ metabolizable energy $/ \mathrm{kg} \mathrm{DM}$ ) and the urea- $\mathrm{N}$ to fish meal-N ratios were $3: 1$ and $0 \cdot 3: 1$.

2. On the four low-energy diets, fish meal inclusion tended to reduce the extent of organic matter (om) digestion in the rumen but significantly increased duodenal amino acid supply $(P<0.05)$ in a quadratic manner. Microbial-N synthesis was increased by the two intermediate levels of fish meal supplementation but declined at the highest level of inclusion. With increasing levels of fish meal inclusion, a greater proportion of the dietary protein was found to escape rumen degradation and the apparent degradabilities of fish meal and maize-silage protein of all four diets were estimated to be 0.22 and 0.73 respectively.

3. The substitution of barley for part of the maize silage enhanced duodenal supply of amino acids, irrespective of the form of the $\mathrm{N}$ supplement, and stimulated microbial amino acid synthesis. For all diets efficiency of microbial-N synthesis was found to vary between 22.5 and $46 \mathrm{~g} \mathrm{~N} / \mathrm{kg}$ rumen-digested om. Contrary to what was found for low-energy diets, the inclusion of fish meal tended to reduce "he flow of dietary protein to the small intestine, but these differences were not statistically significant.

4. The results appertaining to microbial synthesis, dietary protein degradabilities and duodenal amino acid flow for all diets are discussed in relation to the Agricultural Research Council (1980) proposals for the protein requirements of ruminants, and the production responses observed when similar diets were fed to growing cattle.
\end{abstract}

The studies of Thomas \& Wilkinson (1975) on the utilization of maize silage by growing cattle clearly demonstrated the need to supply the diet with extra nitrogen if satisfactory rates of body gains were to be achieved. Subsequently, Cottrill \& Osbourn (1977) examined the protein-N : non-protein-N (NPN) value in the $\mathrm{N}$ supplement to either maize silage or a maize silage-rolled barley mixture $(65: 35, \mathrm{w} / \mathrm{w})$ given alone to young growing cattle. The results of this study showed average daily live weight and empty-body-weight gains to increase as the contribution of fish meal was increased from 20 to $35 \mathrm{~g}$ crude protein $(\mathrm{N} \times 6 \cdot 25) / \mathrm{kg}$ dry matter (DM) consumed whilst at higher levels of fish meal substitution for urea, no further increases were noted. Furthermore, when $350 \mathrm{~g} / \mathrm{kg}$ basal diet was supplied as rolled barley, the ratio of fish meal: urea in the $\mathrm{N}$ supplement was found to have no effect on animal performance.

The study reported in this paper was designed to examine the effect of protein and NPN as $\mathrm{N}$ supplements to diets of either maize silage or maize silage-rolled barley $(65: 35, \mathrm{w} / \mathrm{w})$ on the synthesis of microbial amino acids within the reticulo-rumen and the flow of total protein to the small intestine and to relate these findings to the production responses referred to earlier.

- Present address: Ministry of Agriculture, Fisheries and Food, Block A, Government Buildings, Coley Park, Reading, Berkshire RG1 6DT. 


\section{MATERIALS AND METHODS \\ Preparation of maize silage}

Forage maize (Zea mais cv. GL11) was harvested by means of a metered-chop forage harvester (New Holland, 717) on 24 September 1975, and ensiled directly in a 40 tonne clamp silo and sealed. After 10 months the silo was opened and sufficient silage for the first 2 weeks of the experiment was removed and stored in hessian sacks at $-15^{\circ}$ until required. The silo was then resealed and the whole procedure, which was adopted to minimize waste which would have resulted from daily removal of silage, was repeated every 2 weeks.

\section{Formulation of diets}

Six isonitrogenous ( $24 \mathrm{~g} / \mathrm{kg} \mathrm{DM})$ diets were examined, details of which are given in Table 1 (see p. 531). Diets, MU, MF1, MF2 and MF3 were designed with a concentration of $10.4 \mathrm{MJ}$ metabolizable energy (ME) $/ \mathrm{kg}$ DM with varying proportions of NPN (urea) and protein-N (fish meal). Consequently, maize silage comprised at least $820 \mathrm{~g} / \mathrm{kg}$ total DM offered and contributed between 400 and $440 \mathrm{~g} / \mathrm{kg}$ total $\mathrm{N}$, whilst the small amount of rolled barley-maize starch mixture, included to balance ME with total $\mathrm{N}$ levels, contributed less than $40 \mathrm{~g} / \mathrm{kg}$ total $\mathrm{N}$ in all four diets. Of the remaining dietary $\mathrm{N}$ (average $550 \mathrm{~g} / \mathrm{kg}$ total $\mathrm{N})$ urea-N: fish meal-N values were $3: 1,1 \cdot 4: 1,0 \cdot 6: 1$ and $0 \cdot 3: 1$ respectively.

Diets MBU and MBF3, containing identical levels of urea and fish meal as diets MU and MF3 respectively, were designed to supply $11.3 \mathrm{MJ} \mathrm{ME} / \mathrm{kg} \mathrm{DM}$, with rolled barley comprising 400 and $300 \mathrm{~g} / \mathrm{kg}$ DM respectively. Consequently, maize silage represented approximately $540 \mathrm{~g} / \mathrm{kg}$ total ration DM and supplied $270 \mathrm{~g} / \mathrm{kg}$ total $\mathrm{N}$ in the diet. The rolled barley-maize starch mixture supplied $170 \mathrm{~g} / \mathrm{kg}$ total $\mathrm{N}$ and of the remainder $(550 \mathrm{~g} / \mathrm{kg}$ total $\mathrm{N})$, urea-N and fish meal- $\mathrm{N}$ were present in the proportions $3 \cdot 1: 1$ and $0 \cdot 3: 1$ respectively. In addition, all diets contained a mineral supplement (FSL Dairy Super (Feed Services Livestock) Ltd, Corsham, Wilts.) at a mean inclusion rate of $35 \mathrm{~g} / \mathrm{kg}$ DM and inorganic sulphur (sodium sulphate) to achieve a $\mathrm{N}: \mathrm{S}$ value of $11 \cdot 1$ (Moir et al. 1967). In all instances the diets were prepared and mixed just before feeding.

\section{Animals and their management}

Six Friesian castrated male calves, 10 weeks of age and with a mean body-weight of $92 \mathrm{~kg}$, were group fed on grass silage and concentrates until 14 weeks of age. At this stage, a $38 \mathrm{~mm}$ i.d. rubber cannula (Avon Industrial Polymers Ltd, Bradford-on-Avon, Wilts.) of the type described by Jarrett (1948) was inserted into the dorsal sac of the rumen, and a pair of PVC re-entrant cannulas (i.d. $17 \mathrm{~mm}$, Cammell, 1977) were inserted into the proximal duodenum.

Following surgery, the animals were housed in resting pens and maize silage was introduced into the diet over the next few days. At the commencement of the experiment the six calves were divided randomly into two equal groups. The first group of calves received diets MF3, MU and MF1, in that order, whilst the second group received diets $\mathrm{MBU}, \mathrm{MBF} 3$ and MF2. Individual feed allowances were calculated on a basis of $22 \mathrm{~g} \mathrm{DM} / \mathrm{kg}$ live weight. Approximately $25 \mathrm{~d}$ were allowed as a changeover period from one diet to another. For the first $10 \mathrm{~d}$ calves were kept in resting pens. Thereafter they were weighed, transferred to metabolism crates (Cammell, 1977) and reweighed $7 \mathrm{~d}$ later, the amount of food allocated being adjusted after each weighing. They remained in metabolism crates until measurements were completed. At all times animals were maintained in a semi-controlled environment with continuous lighting, and fresh water was available.

Each animal received its daily feed allowance in two equal feeds at 09.00 and 17.00 hours. Refusals, if any, were lifted and weighed just before the morning feed and dried at $103^{\circ}$ for $24 \mathrm{~h}$ to determine actual DM intakes. At each feeding time $10 \mathrm{~g}$ chromic oxide-impregnated 
paper was administered via the rumen cannula to each animal as an indigestible marker of nutrient flow at the proximal duodenum (MacRae \& Armstrong, 1969).

\section{Experimental procedures}

A constant intraruminal infusion of $\mathrm{Na}_{2}{ }^{35} \mathrm{SO}_{4}(0 \cdot 375 \mu \mathrm{Ci} / \mathrm{ml} ; 20 \mathrm{ml} / \mathrm{h})$ was commenced for all calves, and $16 \mathrm{~h}$ later the duodenal re-entrant cannulas were opened and connected to the automatic duodenal digesta samplers, as described by Canaway \& Thomson (1977). The duodenal collection was maintained for $24 \mathrm{~h}$, during which time the aliquot samples were held on ice, at approximately $2^{\circ}$. At the end of the collection the infusion of radioactive $\mathrm{S}$ was terminated and all duodenal samples were processed immediately. After $3 \mathrm{~d}, 500 \mathrm{ml}$ rumen fluid were taken at 11.00 hours from each animal and a microbial fraction was obtained using the same technique referred to in the following sections for the isolation of duodenal microbial fractions.

\section{Preparation of samples}

Feed. Representative samples of maize silage and the supplements as fed were taken daily and retained over the $8 \mathrm{~d}$ leading up to and including each duodenal sampling period. Subsequently, these were bulked on an equal fresh weight basis to provide one silage and six supplement samples per period. Subsequently, the six silage samples for the whole experiment were chopped, using a Lynhakker Precision Chopper (model 6H ; Geo. Hansen, Copenhagen) and toluene-DM contents were determined. Approximately $2 \mathrm{~kg}$ of each silage sample was frozen, subsequently freeze-dried and finally ground through a small laboratory mill. The samples of the supplements were ground directly and all samples were stored at $-5^{\circ}$ until required for chemical analysis.

Duodenal digesta. Immediately following the 24-h duodenal collection the samples from each animal were separately mixed by means of a Silverson homogenizer (Series L2R; Silverson Machines Ltd, Chesham, Bucks.) and $400 \mathrm{ml}$ were taken for separation of the duodenal microbial fraction. Of this volume, $2 \times 25 \mathrm{ml}$ were removed and frozen immediately for subsequent estimation of ${ }^{35} \mathrm{~S}$ specific activity in total duodenal methionine, whilst the remainder was subjected to low-speed centrifugation (Beever et al. 1974). The supernatant fraction was then centrifuged at $18000 \mathrm{rev} . / \mathrm{min}$ for $30 \mathrm{~min}$ and the resulting duodenal microbial material was washed once with distilled water. Subsequently, the samples were freeze-dried and ground before analysis for ${ }^{35} \mathrm{~S}$-methionine specific activity.

The remainder of the duodenal digesta was again mixed and a further $800 \mathrm{ml}$ were removed, frozen, subsequently freeze-dried and ground through a small laboratory mill, followed by storage at $-5^{\circ}$ until required for anaylsis.

\section{Analysis of samples}

Oven-DM contents of all feed samples were determined by drying in a forced-draught oven at $103^{\circ}$ for $24 \mathrm{~h}$. Toluene-DM of the silage was estimated by the procedure of Dewar $\&$ McDonald (1961). The contents of $\mathrm{OM}$, gross energy (GE), $\mathrm{N}$ and individual amino acids (excluding methionine) were determined on all silage (freeze-dried), supplement (air-dried) and duodenal digesta (freeze-dried) samples using previously described techniques (Beever et al. 1971; Thomson et al. 1972; Beever et al. 1978). Pepsin-insoluble $N$ contents of all feed samples were obtained using the method of Beever et al. (1976). $\mathrm{Cr}_{2} \mathrm{O}_{3}$ contents of all duodenal digesta samples and twenty $\mathrm{Cr}_{2} \mathrm{O}_{3}$ pellets taken at random throughout the experiment, were determined using an atomic absorption technique, based on the earlier method of Christian \& Coup (1954). The duodenal samples and $\mathrm{Cr}_{2} \mathrm{O}_{3}$ pellets were ashed for $16 \mathrm{~h}$ at $550^{\circ}$ followed by digestion with a mixture of sulphuric acid :phosphoric acid and potassium bromate as described by Christian \& Coup (1954), and the concentration of $\mathrm{Cr}$ in the resulting solution was determined by atomic absorption. 
Methionine concentrations of all feed, duodenal and rumen microbial fractions and duodenal digesta were determined by performic acid oxidation (Moore, 1963), whilst the specific activities of the ${ }^{35} \mathrm{~S}$-methionine in whole duodenal digesta and duodenal microbial material were determined using the techniques of Beever $e t$ al. (1974). In addition, full amino acid analysis was undertaken on all rumen microbial samples.

\section{Calculation of results}

The flow of DM to the proximal duodenum of all calves was calculated on the basis of the $\mathrm{Cr}_{2} \mathrm{O}_{3}$ content of each sample in relation to the amount of indigestible marker administered (MacRae \& Armstrong, 1969; MacRae, 1974). The flow of individual nutrients was then calculated on the basis of specific nutrient concentration in the duodenal digesta DM.

The net flow of microbial amino acids to the duodenum of each calf was calculated from the specific activity ratio of duodenal methionine :microbial methionine, the total flow of methionine to the small intestine and the concentration of methionine in the total amino acids of isolated rumen microbial fractions. The undegraded dietary protein flowing to the small intestine was calculated by difference (total amino acids less microbial amino acids) after allowance for likely endogenous protein input which was assumed to be $11 \%$ of total amino acid flow (Beever et al. 1977).

\section{Statistical analysis}

Because of the non-orthogonal design, statistical analysis of the results has been considered in two parts. In the first analysis (A), the response to increments of fish meal supplementation was examined on the low-energy level for linear or quadratic trends. This was achieved by partitioning the $3 \mathrm{df}$ available to estimate the effect of fish meal into linear and quadratic components with a residual term. The second analysis $(B)$ involved estimating the main effects of energy level and inclusion rate of fish meal and their interaction, while excluding the two middle levels of fish meal. Significant interactions would indicate that the trend shown for the low-energy group (from analysis A) would not apply to the high-energy groups. It should be noted, however, that the lack of a significant interaction does not imply that the effect of fish meal supplementation at the high- and low-energy levels follows the same trend. An example of these analyses, including levels of significance and trends derived from the reduced data sets for parameters presented in Tables 3 and 5 , is given in Table 6 . This analysis presupposes that $(a)$ differences between groups of (3) animals which were not assessed were negligible, $(b)$ that the criteria examined were not markedly influenced by the change in age of the calves over the duration of the experimental period ( 3 months) and (c) that treatment order did not significantly influence the results obtained. The limited animal and sampling resources available and the need to complete the experiment within 3 months of the animal's life precluded validation of these assumptions. Treatment means, together with their standard errors, have been calculated on this basis and are given in Tables 2 to 5 .

RESULTS

Composition of diets

The ingredients and the chemical composition of the diets as fed are shown in Table 1. All diets showed similar total $\mathrm{N}$ contents, whilst $\alpha$-amino acid- $\mathrm{N}$ relative to total $\mathrm{N}$ varied between $450 \mathrm{~g} / \mathrm{kg}$ (diet MU) and $680 \mathrm{~g} / \mathrm{kg}$ (diets MF3 and MBF3).

\section{Digestion of $O M$ and $G E$}

The mean level of DM intake achieved for all diets was $21.2 \mathrm{~g} / \mathrm{kg}$ live weight, with only three animals showing small refusals around the time of duodenal collection. The quantity of $\mathrm{Cr}_{2} \mathrm{O}_{3}$ administered amounted to $6.4( \pm 0.219) \mathrm{g} / \mathrm{d}$ and the mean $( \pm \mathrm{SE})$ recovery of 
Table 1. Composition of the six diets as offered ( $\mathrm{g} / \mathrm{kg}$ dry matter (DM) unless stated)

(Silage DM values based on toluene distillation method)

\begin{tabular}{|c|c|c|c|c|c|c|}
\hline Diet... & MU & MF1 & MF2 & MF3 & MBU & MBF3 \\
\hline \multicolumn{7}{|l|}{ Ingredients } \\
\hline Maize silage & 820 & 833 & 852 & 870 & 513 & 566 \\
\hline Urea & 22 & 17 & 12 & 7 & 22 & 7 \\
\hline Fish meal* & 29 & 50 & 71 & 93 & 29 & 93 \\
\hline $\begin{array}{l}\text { Rolled barley-maize } \\
\text { starch }^{\dagger}\end{array}$ & 89 & 63 & 32 & 0 & 396 & 304 \\
\hline Minerals $\ddagger$ & 40 & 37 & 33 & 30 & 40 & 30 \\
\hline \multicolumn{7}{|l|}{ Chemical composition } \\
\hline Organic matter & 928 & 919 & 921 & 934 & 942 & 938 \\
\hline Gross energy (MJ/kg DM) & $19 \cdot 0$ & $19 \cdot 0$ & $19 \cdot 4$ & $19 \cdot 6$ & $19 \cdot 2$ & $19 \cdot 1$ \\
\hline Total nitrogen & $24 \cdot 0$ & 23.8 & $24 \cdot 4$ & $22 \cdot 4$ & 23.8 & $24 \cdot 0$ \\
\hline Pepsin-insoluble $\mathrm{N}$ & 7.84 & 9.63 & $11 \cdot 3$ & 13.00 & 7.79 & $12 \cdot 8$ \\
\hline Total amino acid-N & $10 \cdot 9$ & $12 \cdot 6$ & $14 \cdot 6$ & $16 \cdot 4$ & $12 \cdot 0$ & $16 \cdot 3$ \\
\hline $\begin{array}{l}\alpha \text {-Amino acid-N } \\
(\mathrm{g} / \mathrm{kg} \text { total } \mathrm{N})\end{array}$ & 452 & 529 & 596 & 673 & 504 & 679 \\
\hline
\end{tabular}

- Scotch herring meal.

$\dagger$ Rolled barley-maize starch, $630: 270$ parts $/ \mathrm{kg}$ fresh weight basis.

‡ FSL Dairy Super (Feed Services Livestock) Ltd, Corsham, Wilts.

Table 2. The mean quantities of organic matter $(\mathrm{OM})(\mathrm{kg} / \mathrm{d})$ and gross energy $(\mathrm{GE})(\mathrm{MJ} / \mathrm{d})$ consumed and entering the small intestine of cattle receiving the six diets. The values for the proportion of ingested nutrient apparently digested in the reticulo-rumen are also given

\begin{tabular}{|c|c|c|c|c|c|c|c|}
\hline Diet... & MU & MF1 & MF2 & MF3 & MBU & MBF3 & SEM \\
\hline \multicolumn{8}{|l|}{ OM } \\
\hline Consumed & $3 \cdot 40$ & 3.63 & 3.54 & 3.04 & 3.05 & 3.51 & \\
\hline Entering small intestine & 1.57 & $2 \cdot 01$ & 2.07 & 1.68 & 1.48 & 1.69 & 0.127 \\
\hline $\begin{array}{l}\text { Rumen digestion of } \mathrm{OM} \\
\mathrm{g} / \mathrm{kg} \mathrm{OM}_{\mathrm{I}}\end{array}$ & 536 & 445 & 415 & 461 & 513 & 516 & $25 \cdot 3$ \\
\hline \multicolumn{8}{|l|}{ GE } \\
\hline Consumed & $69 \cdot 6$ & $75 \cdot 0$ & $74 \cdot 2$ & $64 \cdot 3$ & 60.6 & $71 \cdot 1$ & \\
\hline Entering small intestine & $33 \cdot 5$ & $45 \cdot 1$ & $40 \cdot 3$ & $36 \cdot 5$ & $30 \cdot 4$ & $36 \cdot 5$ & 3.41 \\
\hline $\begin{array}{l}\text { Ru.nen digestion of } \mathrm{GE} \\
\text { intake }(\mathrm{kJ} / \mathrm{MJ})\end{array}$ & 517 & 402 & 457 & 435 & 498 & 486 & $38 \cdot 2$ \\
\hline
\end{tabular}

chromic oxide in the 24-h collections of duodenal digesta was $85( \pm 13.1) \%$. Values for om and GE digestion are shown in Table 2. The quantity of om flowing to the small intestine indicated that between 415 and $536 \mathrm{~g} \mathrm{OM} / \mathrm{kg}$ OM intake $\left(\mathrm{OM}_{\mathrm{I}}\right)$ were apparently digested within the reticulo-rumen.

On the low-energy diets, the proportion of om consumed that was apparently digested in the rumen appeared to decrease with increasing levels of fish meal, but the effect was non-significant $(P>0.05)$. On the high-energy diets, no such effect was evident. The proportion of GE apparently digested in the reticulo-rumen varied between 400 and $520 \mathrm{~kJ} / \mathrm{MJ}$ intake, reflecting the changes seen in om digestion. However, no significant dietary differences were observed, whilst the average energy value of the rumen-digested organic matter (RDom) was calculated to be $20.0 \mathrm{MJ} / \mathrm{kg}$. 
Table 3. The mean quantities $(\mathrm{g} / \mathrm{kg}$ organic matter intake) of total and $\alpha$-amino acid-nitrogen consumed and entering the small intestine and the net loss or gain of $N$ constitutents within the reticulo-rumen of cattle receiving the six diets

\begin{tabular}{|c|c|c|c|c|c|c|c|}
\hline Diet. & MU & MF1 & MF2 & MF3 & MBU & MBF3 & SEM \\
\hline \multicolumn{8}{|l|}{ Total $N(g / k g)$} \\
\hline Consumed & 25.9 & $25 \cdot 9$ & $26 \cdot 5$ & $26 \cdot 1$ & $25 \cdot 7$ & $25 \cdot 6$ & \\
\hline $\begin{array}{l}\text { Entering small } \\
\text { intestine }\end{array}$ & $22 \cdot 2$ & $28 \cdot 5$ & $31 \cdot 3$ & $29 \cdot 3$ & $27 \cdot 6$ & $30 \cdot 7$ & $1 \cdot 20$ \\
\hline $\begin{array}{l}\text { Net loss }(-) \text { or } \\
\text { gain }(+) \text { across } \\
\text { reticulo-rumen }\end{array}$ & $-3 \cdot 7$ & $+2 \cdot 6$ & $+4 \cdot 8$ & $+3 \cdot 2$ & +1.9 & $+5 \cdot 1$ & 1.07 \\
\hline \multicolumn{8}{|l|}{$\alpha$-Amino acid-N } \\
\hline Consumed & $11 \cdot 7$ & $13 \cdot 7$ & $15 \cdot 8$ & $17 \cdot 2$ & $12 \cdot 8$ & $17 \cdot 4$ & \\
\hline $\begin{array}{l}\text { Entering small } \\
\text { intestine }\end{array}$ & $14 \cdot 2$ & $18 \cdot 3$ & $20 \cdot 7$ & $20 \cdot 2$ & $18 \cdot 4$ & $21 \cdot 6$ & $1 \cdot 10$ \\
\hline $\begin{array}{l}\text { Net loss }(-) \text { or } \\
\text { gain }(+) \text { across } \\
\text { reticulo-rumen }\end{array}$ & $+2 \cdot 5$ & $+4 \cdot 6$ & $+4 \cdot 9$ & $+3 \cdot 0$ & $+5 \cdot 6$ & $+4 \cdot 2$ & 1.02 \\
\hline
\end{tabular}

\section{Digestion and flow of nitrogenous constituents}

Total and $\alpha$-amino acid- $N$. Because of variations in the quantities of DM consumed by the cattle both within and between diets, owing to different animal live weights and the occurrence of some feed refusals as referred to earlier, the remainder of the results have been expressed per kg ом intake. A similar approach was adopted by Thomson et al. (1981). The intake and flow of total and $\alpha$-amino acid-N are given in Table 3. Intake of total $\mathrm{N}$ was virtually constant on all diets (mean $25.9 \mathrm{~g} \mathrm{~N} / \mathrm{kg}$ om consumed), whilst the flow of total $\mathrm{N}$ to the small intestine increased significantly with increasing levels of fish meal content in the diet at both the low- and high-energy levels (both $P<0.01$ ). On the low-energy diets this increase was best described by a quadratic equation $(P<0.05)$. There was a $13 \%$ increase in the flow of total $\mathrm{N}$ into the small intestine, associated with the increased dietary energy concentration $(P<0.05)$ but the interaction term failed to achieve statistical significance $(P>0.05)$. A similar pattern of significant effects was apparent in the flow of $\alpha$-amino acid-N, with the exception that the trend on the low-energy diets, whilst positive, was linear $(P<0 \cdot 01)$. There was a similar increase in $\alpha$-amino acid-N flow into the small intestine on the high-energy diets $(P<0.05)$.

There was an apparent net loss of $3.7 \mathrm{~g}$ total $\mathrm{N} / \mathrm{kg} \mathrm{OM}_{\mathrm{I}}$ across the reticulo-rumen on diet MU, whilst all other diets showed a net gain. On the low-energy diets there was a significant quadratic trend in this net change of $\mathrm{N}(P<0.05)$ with increasing fish meal supplementation, and a significant positive response to both energy $(P<0.01)$ and fish meal $(P 0.001)$ in the energy $v$. fish meal comparison (analysis B). The apparent net loss of total $\mathrm{N}$ across the reticulo-rumen on diet MU was clearly a reflection of the high proportion of non-amino acid- $\mathrm{N}$ in this diet, since on all diets there was an apparent net gain in $\alpha$-amino acid- $\mathrm{N}$ at the small intestine.

Total and individual amino acids. The intake and flow of total and individual amino acids are shown in Table 4. The flow of total amino acids to the small intestine of calves fed the low-energy diets increased significantly with increasing levels of fish meal supplementation $(P<0.01)$, such that there was a $44 \%$ difference between the lowest (MU) and highest (MF2 and MF3) fish meal diets. The mean effect of increasing the energy concentration of the diets was a $17 \%$ increase in total amino acid flow $(P<0.05)$. In the energy $v$. fish meal 


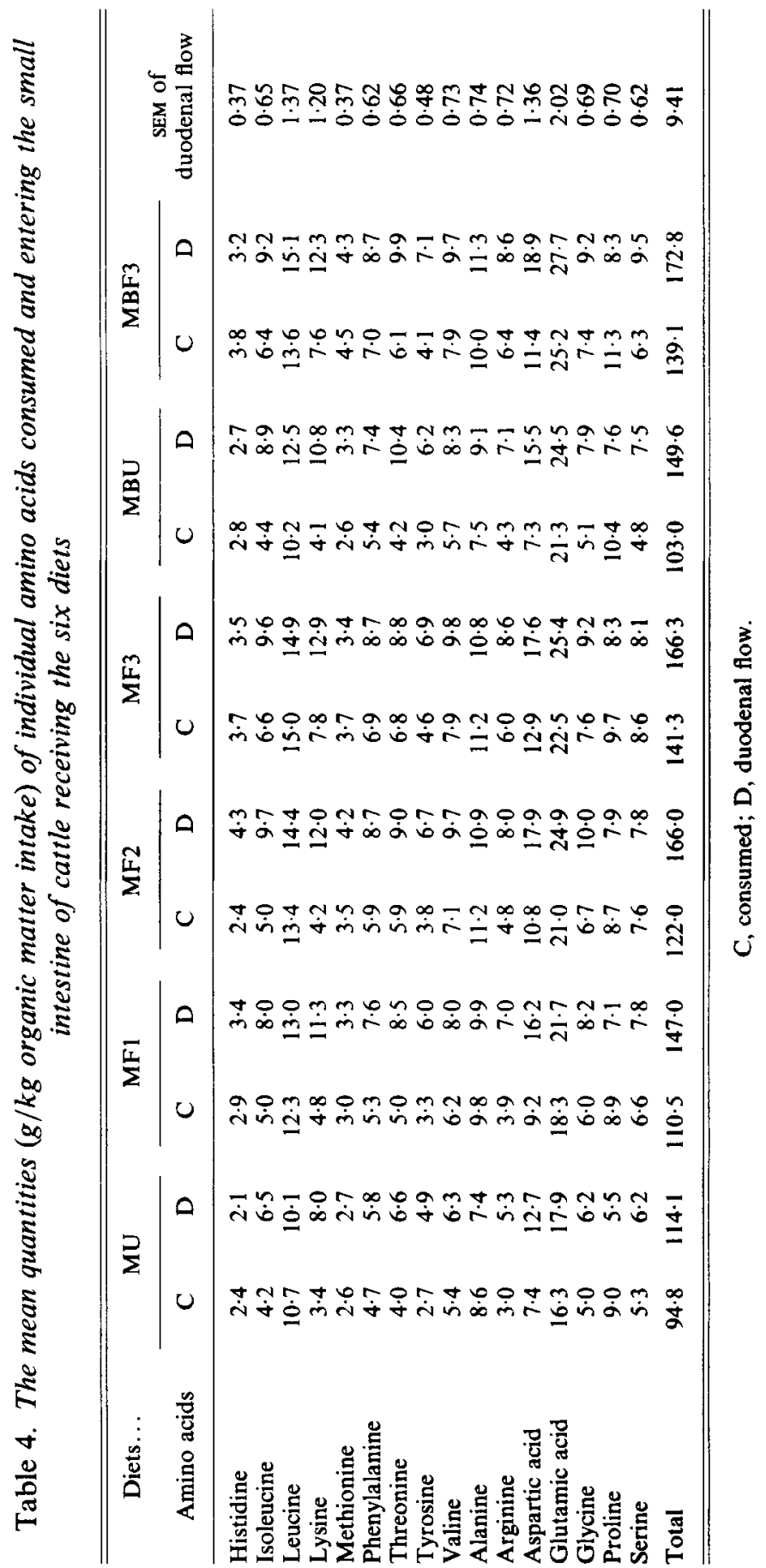


Table 5. The net extent and efficiency of microbial amino acid synthesis in the rumen, and the extent of degradation of dietary protein for the six diets fed to cattle

\begin{tabular}{|c|c|c|c|c|c|c|c|}
\hline Diets. & MU & MF1 & MF2 & MF3 & $\mathrm{MBU}$ & MBF3 & SEM \\
\hline \multicolumn{8}{|l|}{ Total amino acids $(\mathrm{g} / \mathrm{kg} \mathrm{OM})_{1}$} \\
\hline Consumed & 94.7 & $110 \cdot 5$ & $121 \cdot 9$ & $141 \cdot 1$ & $103 \cdot 0$ & $139 \cdot 0$ & \\
\hline \multicolumn{8}{|l|}{ Entering small intestine } \\
\hline Total & $114 \cdot 1$ & $147 \cdot 1$ & $166 \cdot 1$ & $166 \cdot 3$ & $149 \cdot 5$ & $172 \cdot 6$ & $9 \cdot 41$ \\
\hline Microbial & $63 \cdot 1$ & 91.7 & 96.6 & $70 \cdot 4$ & $85 \cdot 2$ & $131 \cdot 1$ & $10 \cdot 69$ \\
\hline Undegraded dietary* & $38 \cdot 4$ & $39 \cdot 1$ & $51 \cdot 1$ & $77 \cdot 6$ & $47 \cdot 9$ & $22 \cdot 5$ & 7.64 \\
\hline $\begin{array}{l}\text { Microbial amino acid } \\
\text { synthesis (g/kg RDom) }\end{array}$ & 118 & 209 & 231 & 151 & 168 & 254 & $26 \cdot 1$ \\
\hline $\begin{array}{l}\text { A pparent degradability of } \\
\text { dietary protein }(\mathrm{g} / \mathrm{kg} \text { amino } \\
\text { acid intake }\end{array}$ & 595 & 645 & 580 & 455 & 537 & 838 & $56 \cdot 1$ \\
\hline
\end{tabular}

$\mathrm{OM}_{\mathrm{I}}$, Organic matter intake; RDoM, rumen digested organic matter.

* Calculated as total amino acids at the duodenum minus (microbial amino acids plus endogenous amino acid contribution). Endogenous amino acid contribution is assumed to be $11 \%$ of the total amino acid flow (Beever et al. 1977).

comparison, increasing fish meal in the dietary DM resulted in a $27 \%$ increase in total amino acid flow to the small intestine $(P<0.01)$.

Of the individual amino acids, only serine flow at the small intestine failed to increase significantly with increasing fish meal in the low-energy diets. All other amino acids showed a significant response $(P<0.05)$. Generally, the response was linear, but for histidine $(P<0.01)$ and methionine, glycine and alanine $(P<0.05)$ the change in amino acid flow was best described by quadratic equations. Increasing the energy concentration in the diets resulted in increased flow to the small intestine of methionine, tyrosine, glutamic acid $(P<0.01)$ and threonine $(P<0.001)$, whilst the effect of increasing fish meal in the energy $v$. fish meal comparison was to increase the flow of all amino acids $(P<0.05)$ with the exception of threonine.

Clearly some of these differences will have been influenced by the different amounts of individual amino acids consumed on the different diets. To consider this further, the duodenal flow of individual amino acids was calculated per unit individual amino acid consumed $(\mathrm{g} / \mathrm{g})$ and analysed according to the statistical procedures outlined in analyses A and B. On the low-energy diets, only histidine $(P<0.001)$ and proline, threonine, serine, isoleucine and lysine $(P<0.05)$ showed significant responses to the level of fish meal in the diet. Both threonine and serine showed linear negative trends with increasing level of fish meal. The flows of the remaining amino acids increased with increasing level of fish meal and were best described by quadratic equations. From analysis B, increasing the level of energy in the diet was associated with elevated flows of threonine and serine $(P<0.001)$, aspartic acid and alanine $(P<0.01)$ and glycine, isoleucine and tryosine $(P<0.05)$, whilst the increased intake of fish meal increased the flows of threonine and lysine $(P<0.001)$, aspartic acid, isoleucine and tyrosine $(P<0.01)$ and proline, glycine, arginine and methionine $(P<0.05)$.

\section{Microbial amino acid flow to the small intestine and efficiency of microbial amino acid synthesis}

As stated earlier, the estimates of microbial synthesis were derived using the ${ }^{35} \mathrm{~S}$ technique as proposed and validated by Beever et al. (1974). The variations in estimates of microbial protein synthesis which have been demonstrated when different techniques were applied to 
similar diets fed to the same animals are quite disturbing (Ling \& Buttery, 1978; Siddons et al. 1982). However, in both of these comparisons, the authors appeared to find ${ }^{35} \mathrm{~S}$ a more reliable marker than some of the others currently being used.

The net flow of microbial amino acids to the small intestine $(\mathrm{g} / \mathrm{kg} \mathrm{oM})$ for each treatment is given in Table 5. On the low-energy diets there was an increase in the flow of microbial amino acids with each of the first two increments of fish meal, but on the diet containing most fish meal (MF3) a value closer to that found on diet MU was recorded and consequently the level of fish meal in the low-energy diets did not significantly increase microbial amino acid flow to the small intestine. In the energy $v$. fish meal comparison (analysis B) the increase in energy concentration in the diets resulted in a $49 \%$ increase in microbial amino acid flow to the small intestine $(P<0.05)$ but neither the increase in microbial flow resulting from the higher level of fish meal in the diet nor the energy $v$. fish meal interaction reached statistical significance.

The efficiency of microbial amino acid synthesis had a mean value of $189( \pm 31.6) \mathrm{g} / \mathrm{kg}$ RDom for all treatments, with the lowest and highest values being observed on diets $\mathrm{MU}$ $(118 \mathrm{~g} / \mathrm{kg})$ and MBF3 $(254 \mathrm{~g} / \mathrm{kg})$ respectively. No significant effects of the level of energy or of fish meal on the efficiency of synthesis were found.

\section{The flow of dietary protein to the small intestine and the apparent degradability of dietary protein in the rumen}

The calculated quantities of undegraded dietary protein flowing to the small intestine and the apparent degradabilities are given in Table 5. On the low-energy diets there was a significant and positive linear trend in the flow of dietary protein associated with increasing levels of fish meal $(P<0.01)$, with an increase of $102 \%$ between MU and MF3. On the high-energy diets the inclusion of fish meal tended to reduce the flow of dietary protein to the small intestine. However, the effects of level of energy and level of fish meal inclusion in analysis $\mathrm{B}$ were not significant $(P<0.05)$ but the energy $v$. fish meal interaction term was significant $(P<0.05)$.

Degradability of dietary protein was calculated as total dietary amino acids consumed less dietary amino acids estimated to enter the small intestine per unit dietary amino acids consumed, and expressed as $\mathrm{g} / \mathrm{kg}$ dietary amino acids consumed. The over-all degradability of all diets varied between 450 and $840 \mathrm{~g} / \mathrm{kg}$ total amino acids consumed. On the low-energy diets there was a trend for degradability to decline with increasing levels of fish meal in the diet, but this was not significant $(P>0.05)$. In analysis $B$ higher degradability was associated with both increased energy and fish meal levels. However, only the interaction term was significant $(P<0 \cdot 05)$.

\section{DISCUSSION}

The results of the present experiment demonstrate that the isonitrogenous substitution of urea with fish meal, or the inclusion of barley in a maize silage-based diet, markedly increased the flow of both total $\mathrm{N}$ and total amino acids to the duodenum of young cattle. The highest levels of fish meal inclusion (diets MF3 and MBF3) when compared with the lowest levels of inclusion (MU and MBU) increased amino acid intake from 99 to $140 \mathrm{~g} / \mathrm{kg}$ $\mathrm{OM}_{\mathrm{I}}$, whilst $\mathrm{N}$ intakes remained constant and resulted in an increased duodenal flow of amino acids (132-169 $\mathrm{g} / \mathrm{kg} \mathrm{OM}$ ), equivalent to an apparent recovery at the duodenum of $90 \%$ of the extra dietary amino acids supplied. On the other hand, increased energy density of the diet (MU and MF3 v. MBU and MBF3) had virtually no effect on total amino acid intake but increased duodenal flow from 140 to $165 \mathrm{~g} / \mathrm{kg} \mathrm{OM}$.

Within the low-energy diets, the two middle levels of fish meal inclusion increased total duodenal amino acid supply by 33 and $52 \mathrm{~g} / \mathrm{kg} \mathrm{OM}_{\mathrm{I}}$ respectively, compared with the control 
B. R. COTTRILL AND OTHERS

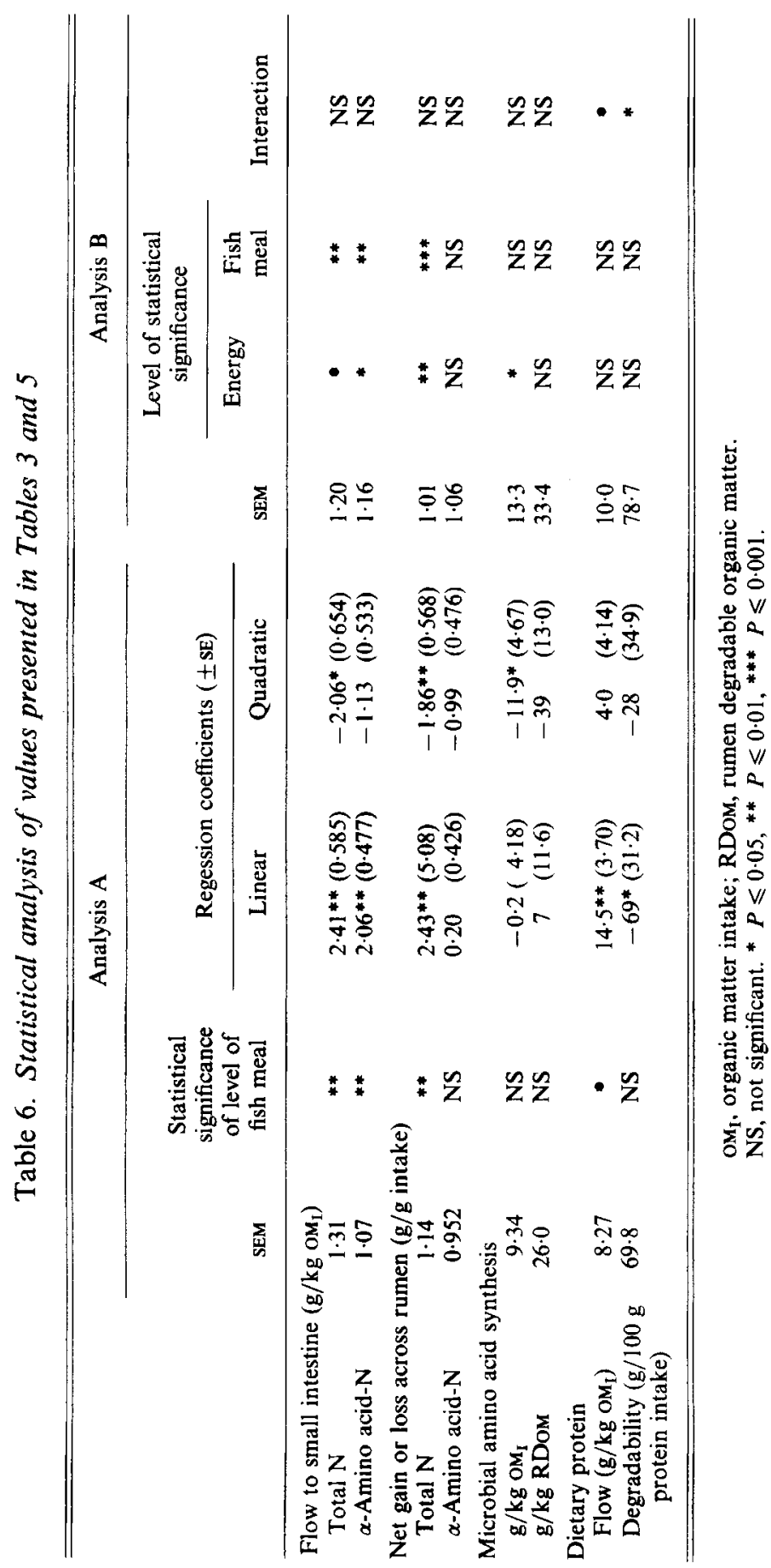


diet, and it appeared that both an increased synthesis of microbial amino acids and an elevated outflow of undegraded dietary protein contributed to these changes. At the highest level of fish meal inclusion, microbial amino acid flow to the small intestine was only slightly greater than the value observed on the control diet and consequently $75 \%$ of the extra duodenal supply of amino acids $\left(52 \mathrm{~g} / \mathrm{kg} \mathrm{OM}_{\mathrm{I}}\right)$ was attributed to an elevated passage of undegraded dietary protein $\left(39 \mathrm{~g} / \mathrm{kg} \mathrm{OM} \mathrm{M}_{\mathrm{Y}}\right)$.

Despite these changes, amino acid composition of duodenal digesta was markedly similar for all diets. On the low-energy diets, fish meal inclusion up to diet MF2 increased the histidine content of duodenal amino acids by $40 \%$, whereas diets MF3 and the two high-energy diets showed no such response. On the other hand, threonine levels declined at each level of fish meal inclusion. For all diets, methionine concentration in duodenal digesta varied between 20 and $26 \mathrm{~g} / \mathrm{kg}$ total amino acids, with the highest values being observed on diets MF2 and MBF. When Gill \& Beever (1982) supplemented a grass silage diet with fish meal, similar increases in methionine supply were observed, but neither study has elucidated the possible cause of this response.

Further examination of the results relating to the quantities of microbial amino acid and dietary protein flowing to the small intestine of cattle given the four low-energy diets was undertaken to obtain estimates of the in vivo degradability of the fish meal and maize silage protein. Regressing the flow of dietary protein to the small intestine (Table 5), expressed per $\mathrm{kg}$ maize silage DM intake $(Y) v$. level of fish meal amino acid inclusion $/ \mathrm{kg}$ maize silage DM intake $(X)$, in a manner similar to that adopted by Hvelpund \& Moller (1980), gave the following equation:

$$
Y=0.778( \pm 0 \cdot 2075) X+18.01( \pm 10 \cdot 742)
$$

where $n 12, r 0.765$ and residual $\mathrm{SD} \pm 12.98$.

From this it may be concluded that on this diet, with maize silage comprising $820 \mathrm{~g} / \mathrm{kg}$ total dietary DM and fed at $22 \mathrm{~g} \mathrm{DM} / \mathrm{kg}$ live weight to young calves, supplemental fish meal protein had an apparent degradability of $0 \cdot 22$. This is slightly lower than the values of $0 \cdot 29$ and 0.30 reported by Hume (1974) and Mercer \& Annison (1976), but until a more direct method of measuring feed-protein degradability is developed, all estimates must be treated with some caution.

Examination of the intercept indicated that for maize silage, total $\mathrm{N}$ and total amino acid degradabilities were 0.79 and 0.73 respectively, if $100 \%$ degradation of all non-urea, non-amino acid- $\mathrm{N}$ in the maize silage diets (average $3.8 \mathrm{~g} \mathrm{~N} / \mathrm{kg} \mathrm{DM}$ ) was assumed. At the highest levels of fish meal inclusion (diets MF2 and MF3) the results exhibited positive curvilinearity with respect to dietary amino acid flow, but a polynominal curve did not improve statistical resolution of the results or aid biological interpretation. Consequently, this phenomenon was not pursued, but the possibility of a non-linear response in undegraded dietary protein flow to increments of protein of relatively low digestibility must not be dismissed.

The use of only two high-energy diets prevented application of the regression approach to the derived values. However, the values revealed an unexpected significant interaction between the level of fish meal and energy concentration of the diet. Barley inclusion in the low-fish meal diet (MBU) appeared to stimulate microbial amino acid synthesis and gave a small increase in the quantity of undegraded dietary protein flowing to the small intestine. On the other hand, the high-energy, high-fish meal diet (MBF3) led to a marked stimulation of microbial amino acid synthesis, with an apparent reduction in the flow of dietary protein to the small intestine compared with the high-energy, high-urea diet (MBU). Clearly, if such results are subsequently confirmed, this phenomenon merits further examination, suggesting as it does that the inclusion of barley (in diets similar to the ones used in this experiment) 


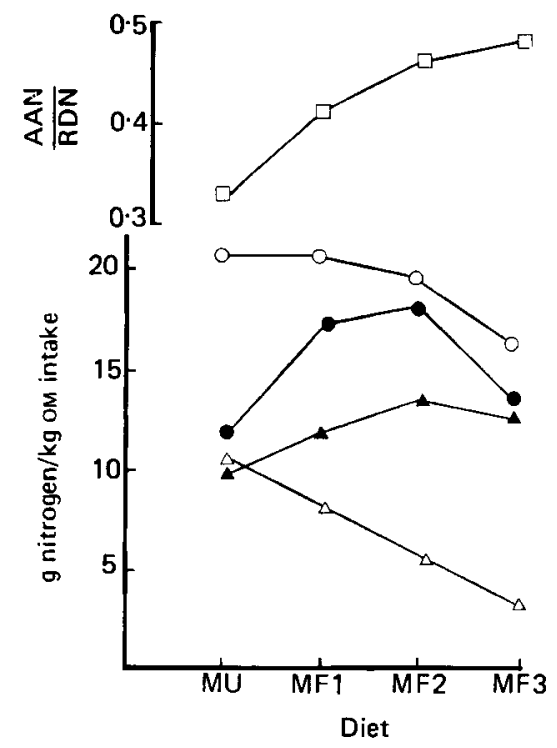

Fig. 1. The quantities of rumen-degradable nitrogen (RDN) $(\mathrm{O}--\mathrm{O})$ derived from urea $(\triangle-\triangle)$ and degraded dietary protein ( $\mathbf{\Delta} \mathbf{\Delta}$ ), the proportion of RDN present in the form of $\alpha$-amino acid-nitrogen (AAN) ( $\square-\square$ ) and the effect of these on microbial-N synthesis ( $-O$ ) for the four low-energy diets (MU, MF1, MF2 and MF3; for details, see p.528).

may not simply increase microbial synthesis but may also lead to an increase in the degradation of dietary protein.

On the four low-energy diets, efficiency of microbial amino acid synthesis varied from 118 to $231 \mathrm{~g} / \mathrm{kg}$ RDom, equivalent to 22.5 to $43.9 \mathrm{~g}$ microbial N/ $\mathrm{kg}$ RDom if the value of $0 \cdot 191 \mathrm{~g} \mathrm{~N} / \mathrm{g}$ amino acid in microbial material reported by Siddons et al. (1979) is adopted. These values depart considerably from the average value of $30 \mathrm{~g} \mathrm{~N} / \mathrm{kg}$ RDom suggested by the Agricultural Research Council (1980) and, further, indicate that efficiency was improved by the isonitrogenous substitution of non-protein- $\mathrm{N}$ with protein- $\mathrm{N}$ up to diet MF2. The highest level of fish meal inclusion caused efficiency to decline to a value $(28.8 \mathrm{~g}$ $\mathrm{N} / \mathrm{kg}$ RDom) only $25 \%$ greater than the value observed on the control diet. To interpret these findings, the relationships between rumen-degradable $\mathbf{N}(\mathrm{RDN})$, its composition and over-all synthesis have been examined in Fig. 1. Total RDN supply was calculated from total urea-N supply and degraded $\alpha$-amino acid- $\mathrm{N}$ supply (see below) and was found to decline in a more or less linear manner from $21 \cdot 2$ to $16.5 \mathrm{~g} / \mathrm{kg} \mathrm{OM}_{\mathrm{I}}$ from diet MU to MF3. This was due almost entirely to a linear decline in urea- $\mathrm{N}$ supply from $11 \cdot 1$ to $3.5 \mathrm{~g} / \mathrm{kg} \mathrm{OM}$, with degraded $\alpha$-amino acid- $N$ supply (calculated from total amino acid intake and measured dietary amino acid degradability) varying very little $\left(7 \cdot 0-9 \cdot 2 \mathrm{~g} / \mathrm{kg} \mathrm{oM}_{\mathrm{I}}\right)$. The over-all effect of this, however, was that degraded $\alpha$-amino acid- $N$ represented only $330 \mathrm{~g} / \mathrm{kg}$ total RDN on diet MU, but this increased linearly to $490 \mathrm{~g} / \mathrm{kg}$ on diet MF3. In response to these changes, microbial-N synthesis was low on diet $\mathrm{MU}\left(12 \cdot 1 \mathrm{~g} \mathrm{~N} / \mathrm{kg} \mathrm{OM}_{1}\right)$ (despite a high availability of RDN) with apparent microbial- $N$ capture being equivalent to only $570 \mathrm{~g} / \mathrm{kg}$ total RDN supply. On diet MF1, a slightly reduced RDN supply, but a marked change in its composition, appeared to stimulate microbial-N synthesis (apparent microbial-N capture being $830 \mathrm{~g} / \mathrm{kg} \mathrm{RDN}$ ) and this response was further maintained with diet MF2. Thereafter, microbial-N synthesis appeared to become a function of total RDN supply rather than its composition, and over-all synthesis fell in response to a diminished supply. On the basis of this approach, the values for the efficiency of microbial-N synthesis 
Table 7. The effect of applying different efficiency values for microbial nitrogen synthesis on the rumen-degradable and undegradable dietary $N$ requirements of a $150 \mathrm{~kg}$ steer consuming a maize-silage-based diet formulated to sustain a daily live weight gain of $1 \mathrm{~kg}$

\begin{tabular}{lccc}
\hline \hline Microbial N synthesis (g/kg RDoM)... & $\begin{array}{c}30 \\
\text { Agricultural } \\
\text { Research Council } \\
(1980)\end{array}$ & $\begin{array}{c}22.5 \\
\text { Diet MU } \\
\text { (present } \\
\text { study) }\end{array}$ & $\begin{array}{c}44.0 \\
\text { Diet MF2 } \\
\text { (present } \\
\text { study) }\end{array}$ \\
Source of values... & 46.5 & 46.5 & 46.5 \\
ME requirements (MJ/d) & 58.2 & 43.7 & 85.1 \\
RDN requirement (g/d) & 24.7 & 18.6 & 36.3 \\
Total microbial N supply (g/d) & 30.3 & 30.3 & 30.3 \\
Tissue N requirement (g/d) & 5.6 & 11.7 & - \\
Tissue N deficit (g/d) & 10.7 & 22.2 & 85.1 \\
UDN requirement (g/d) & 68.9 & 65.9 & 19.0 \\
Total dietary N requirement (g/d) & 15.4 & 14.7 & 1.00 \\
(g/kg DM $)$ & 0.84 & 0.66 & \\
Dietary N degradability & & & \\
\hline \hline
\end{tabular}

RDOM, rumen digested organic matter; ME, metabolizable energy; RDN, rumen degradable nitrogen; UDN, undegradable nitrogen; $\mathrm{DM}_{1}$, dry matter intake.

obtained on diets MU and MF3 were compared with those for diets MF1 and MF2, and the over-all difference between the two groups was found to be statistically significant $(P<0 \cdot 05)$. Such a finding tends to support the conclusions drawn from Fig. 1 that RDN supply (diet MF3) or RDN composition (diet MU) may have depressed the efficiency of microbial-N synthesis. Further experimentation is required to confirm these findings.

In vivo comparisons of such values are not readily available, but the earlier work of Bryant \& Robinson (1962), and the studies of Maeng \& Baldwin (1976), have indentified the need to supply some degradable $\alpha$-amino acid-N along with NPN sources if maximum microbial growth rates are to be achieved. These findings, along with the results of the present study, provide a reasonable basis to suggest that the failure to acknowledge the effect of the amino acid composition of RDN in the current Agricultural Research Council (1980) proposals is a serious omission.

Applying the value of 0.8 for maximum utilization of urea, as suggested by the Agricultural Research Council (1980), displaced the RDN supply curve slightly downwards, but the over-all effect of composition of RDN was still evident and suggests that the current adeption of 0.8 for NPN utilization may be an over-estimate.

For all diets, microbial- $\mathrm{N}$ synthesis varied between $22 \cdot 5$ and $46 \cdot 0 \mathrm{~g} / \mathrm{kg}$ RDoM. The impact that variation of this magnitude may have on dietary $\mathrm{N}$ requirements, and in particular RDN and undegradable dietary $N$ (UDN) required to maximize both rumen microbial function and host tissue metabolism, is illustrated in Table 7. In formulating a maize silage-based diet sufficient for a $150 \mathrm{~kg}$ steer with a desired daily live weight gain of $1 \mathrm{~kg}$, the effect of using the lowest and highest values for the efficiency of microbial- $\mathrm{N}$ synthesis observed on the low-energy diets (diets MU and MF2) is contrasted with the value of $30 \mathrm{~g}$ $\mathrm{N} / \mathrm{kg}$ RDom, all other criteria relating to $\mathrm{N}$ absorption and utilization and $\mathrm{ME}$ requirement being those given by the Agricultural Research Council (1980).

With an efficiency of $22.5 \mathrm{~g} \mathrm{~N} / \mathrm{kg}$ RDom, the total $\mathrm{N}$ requirement $(65.9 \mathrm{~g} / \mathrm{d})$ was calculated to be only $5 \%$ lower than the value derived using the Agricultural Research Council (1980) estimate of efficiency, but there was a marked reduction in RDN requirement, due to the lower efficiency of microbial-N synthesis. Consequently, UDN requirement was doubled to overcome the shortfall in tissue $N$ supply, with the net result that optimum degradability declined from 0.84 (Agricultural Research Council, 1980) to 
0.66 . On the other hand, the highest estimate of microbial- $\mathrm{N}$ synthesis gave a total $\mathrm{N}$ requirement of almost $25 \%$ greater than the Agricultural Research Council (1980) estimate, due entirely to a greater RDN requirement. This, in turn, was calculated to give a microbial-N yield in excess of tissue $\mathbf{N}$ requirements and consequently a zero requirement of UDN was estimated.

Clearly, the requirements of the animal for RDN and UDN, and hence total $\mathrm{N}$ in the diet, can be dramatically affected by the values adopted within the current Agricultural Research Council proposals. The values in Table 7 indicate that optimal dietary $\mathrm{N}$ level may vary between 14.7 and $19.0 \mathrm{~g} / \mathrm{kg} \mathrm{DM}$. Within the context of these findings, the need for greater precision and possibly a reappraisal of some of the approaches adopted by the Agricultural Research Council (1980) are obvious.

In a previous experiment (Cottrill \& Osbourn, 1977) the same diets were fed ad lib. to 3-month-old non-fistulated Friesian male calves for a period of $97 \mathrm{~d}$. On the low-energy diets the increased inclusion of fish meal (MF1 v. MU) led to a $21 \%$ improvement in live weight gain; a response apparently mediated through the elevated duodenal flow of total amino acids seen on diet MF1 compared with diet MU. Thereafter, no further increases in the rate of live weight gain were observed with higher rates of fish meal inclusion, despite small increases in total duodenal amino acid flow on these diets (MF2 and MF3). On the two high-energy diets examined in this study, Cottrill \& Osbourn (1977) recorded live weight gains $(1 \cdot 1 \mathrm{~kg} / \mathrm{d})$ which were not significantly different from each other or the values recorded on diets MF1, MF2 and MF3. Application of the results of the present study to those of the production experiment suggested that the inclusion of fish meal or other protected proteins in maize silage diets for young growing cattle, at a rate sufficient to elevate the flow of total amino acids to the duodenum to approximately $150 \mathrm{~g} / \mathrm{kg} \mathrm{OM}$, had a beneficial response in terms of live weight and empty-body-weight gain. There appeared to be no advantage in increasing total duodenal amino acid supply above this level and, furthermore, in situations where the elevated flow was achieved, the origin of the amino acids (i.e. dietary or microbial) appeared to have no measurable effect on animal performance.

The authors wish to acknowledge the generosity of the International Association of Fish Meal Manufacturers in supplying the herring meal used in this experiment. We wish to thank Messrs M. J. Haines, R. T. Evans, S. B. Cammell and S. Powell for technical assistance and care of the animals, Mr R. J. Barnes, Mr R. A. Terry, Mrs A. S. Keene and Miss R. L. J. Nixon for chemical analyses and Mr M. S. Dhanoa and Mrs J. F. B. Altman (Rothamsted Experimental Station) for statistical advice and analysis. One of us (B.R.C.) gratefully acknowledges the receipt of an ARC Postgraduate Scholarship. The Grassland Research Institute is financed through the Agricultural Research Council.

\section{REFERENCES}

Agricultural Research Council (1980). The Nutrient Requirements of Ruminant Livestock, p. 121. London: Agricultural Research Council.

Beever, D. E., Harrison, D. G., Thomson, D. J., Cammell, S. B. \& Osbourn, D. F. (1974). Br. J. Nutr. $32,99$.

Beever, D. E., Terry, R. A., Cammell, S. B. \& Wallace, A. S. (1978). J. agric. Sci., Camb. 90, 463.

Beever, D. E., Thomson, D. J. \& Cammell, S. B. (1976). J. agric. Sci., Camb. 86, 443.

Beever, D. E., Thomson, D. J., Cammell, S. B. \& Harrison, D. G. (1977). J. agric. Sci., Camb. 88, 61.

Beever, D. E., Thomson, D. J., Pfeffer, E. \& Armstrong, D. G. (1971). Br. J. Nutr. $26,123$.

Bryant, M. P. \& Robinson, I. M. (1962). J. Bact. 84, 605.

Cammell, S. B. (1977). Tech. Rep. Grassld Res. Inst., Hurley no. 24.

Canaway, R. J. \& Thomson, D. J. (1977). Tech. Rep. Grassld Res. Inst., Hurley no. 23.

Christian, K. R. \& Coup, M. R. (1954). N. Z. Jl Sci. Tech. 36A.

Cottrill, B. R. \& Osbourn, D. F. (1977). Anim. Prod. 24, 127. 
Dewar, W. A. \& McDonald, P. (1961). J. Sci. Fd Agric. 12, 790.

Gill, M. E. \& Beever, D. E. (1982). Br. J. Nutr. 48, 37.

Hume, I. D. (1974). Aust. J. agric. Res. 25, 155.

Hvelpund, T. \& Moller, P. D. (1980). Publs. Eur. Ass. Anim. Prod. no. 27.

Jarrett, I. G. (1948). J. Counc. Sci. Ind. Res. Aust. 21, 311.

Ling, J. R. \& Buttery, P. (1978). Br. J. Nutr. 39, 165.

MacRae, J. C. (1974). Proc. Nutr. Soc. 33, 147.

MacRae, J. C. \& Armstrong, D. G. (1969). Br. J. Nutr. 23, 15.

Maeng, W. J. \& Baldwin, R. L. (1976). J. Dairy Sci. 59, 648.

Mercer, J. R. \& Annison, E. F. (1976). Publs. Eur. Ass. Amin. Prod. no. 16.

Moir, R. J., Somers, M. \& Bary, A. C. (1967). Sulph. Inst. J. 3, 15.

Moore, S. (1963). J. biol. Chem. 233, 235.

Siddons, R. C., Beever, D. E. \& Nolan, J. V. (1982). Br. J. Nutr. 48, 377.

Siddons, R. C., Evans, R. T. \& Beever, D. E. (1979). Br. J. Nutr. 42, 535.

Thomas, C. \& Wilkinson, J. M. (1975). J. agric. Sci., Camb. 85, 255.

Thomson, D. J., Beever, D. E., Coelho da Silva, J. F. \& Armstrong, D. G. (1972). Br. J. Nutr. $28,31$.

Thomson, D. J., Beever, D. E., Lonsdale, C. R., Haines, M. J., Cammell, S. B. \& Austin, A. R. (1981). Br. J. Nutr. 46, 193. 